\title{
Prevalensi dan Kepekaan Bakteri Enteropatogen terhadap Antibiotik pada Monyet Ekor Panjang dengan Diare di Fasilitas Penangkaran Institut Pertanian Bogor di Dramaga
}

\author{
(PREVALENCE AND SENSITIVITY OF ENTEROPATHOGENIC BACTERIA \\ IN DIARRHEAGENIC LONG-TAIL MACAQUE IN THE BREEDING \\ FACILITIES OF IPB UNIVERSITY AT DRAMAGA, BOGOR) \\ Fhady Risckhy Loe ${ }^{1}$, Suzy Tomongo ${ }^{3}$, Uus Saepuloh ${ }^{2,3}$, \\ Dondin Sajuthi ${ }^{2,3}$, Irma H Suparto ${ }^{2,3}$ \\ ${ }^{1}$ Sekolah Pascasarjana, Institut Pertanian Bogor \\ Babakan, Dramaga, Bogor, Jawa Barat, Indonesia 16680 \\ ${ }^{2}$ Program Studi Primatologi, \\ Sekolah Pascasarjana, Institut Pertanian Bogor \\ Jl. Lodaya II, Bogor, Jawa Barat, Indonesia 16151 \\ ${ }^{3}$ Pusat Studi Satwa Primata, \\ Lembaga Penelitian dan Pengabdian kepada Masyarakat, \\ Institut Pertanian Bogor \\ Jl. Lodaya II, Bogor, Jawa Barat, Indonesia 16151 \\ E-mail: fhadyrisckhy05@gmail.com.
}

\begin{abstract}
Long-tailed macaque (Macaca fascicularis) is one of the important laboratory animals in biomedical research. Breeding facilities for the laboratory animals are regulated and supported by the rules of animal welfare and also health management. One of the problem that often occur in a breeding facilities is diarrhea, including at breeding facilities of IPB (Institut Pertanian Bogor) Darmaga. Diarrhea affected the breeding productivity due to the high morbidity and mortality. Enteropathogenic bacteria is one of the cause of diarrhea, that can be transmitted between animals also through water and feeds. Therefore, the aims of this study were to identify and determine the prevalence including its microbial susceptibility of the enterobacteria, which cause diarrhea to the long-tailed macaques at Darmaga breeding facilities and also from their feed and drinking water sources. A total of thirty fecal samples, six water samples and two feed samples were collected then examined for the presence of enterobacteria. Standard microbiological methods were used to isolate and identify enterobacteria from stool samples also characterized the antimicrobial susceptibility. Water and feeds were tested using the most probable number method. The results of isolation and bacterial identification from fecal samples were E. coli (100\%), Salmonella sp. (97\%) and Shigella sp. (60\%). E. coli and coliform contamination in water and feed samples (banana and monkey chow) were detected above the minimum limit. All enterobacteria were sensitive to ciprofloxacin and gentamicin but resistant to erythromycin.
\end{abstract}

Key words: antibiotics; enteropathogenic bacteria; feed; long-tailed macaque; water

\begin{abstract}
ABSTRAK
Monyet ekor panjang (Macaca fascicularis) adalah salah satu hewan laboratorium dalam penelitian biomedis. Fasilitas penangkaran untuk hewan laboratorium diatur dan didukung oleh kaidah kesejahteraan hewan dan manajemen kesehatan yang baik. Salah satu masalah yang sering terjadi di fasilitas penangkaran adalah diare, termasuk di fasilitas penangkaran IPB Dramaga. Diare menyebabkan penurunan produktivitas karena tingginya morbiditas dan mortalitas. Bakteri enteropatogenik adalah salah satu penyebab diare yang dapat ditularkan antar hewan juga melalui air dan pakan. Oleh karena itu, tujuan dari penelitian ini adalah untuk mengidentifikasi prevalensi bakteri enteropatogen pada sampel feses, air dan pakan, menguji kepekanan bakteri enteropatogen terhadap antibiotik dari sampel
\end{abstract}


feses di fasilitas penangkaran Dramaga. Sebanyak 30 sampel feses, enam sampel air dan dua sampel pakan dikoleksi kemudian diuji untuk mengetahui adanya bakteri enteropatogen. Metode mikrobiologis standar digunakan untuk mengisolasi dan mengidentifikasi bakteri enteropatogen dari sampel feses dan pengujian kepekaan antibiotik.. Air dan pakan diuji menggunakan metode angka paling mungkin. Hasil isolasi dan identifikasi bakteri dari sampel feses adalah E. coli (100\%), Salmonella enteritidis (97\%) dan Shigella sp. (60\%). Kontaminasi E. coli dan coliform dalam sampel air dan pakan (pisang dan monkey chow) terdeteksi di atas batas minimum (0/100 mL/g). Semua bakteri enteropatogen sensitif terhadap siprofloksasin dan gentamisin tetapi resisten terhadap eritromisin.

Kata-kata kunci: antibiotik; bakteri enteropatogen; pakan; monyet ekor panjang; air

\section{PENDAHULUAN}

Kemajuan penelitian biomedis tidak terlepas dari pengembangan kapasitas dan kapabilitas institusi dalam pengelolaan dan penggunaan hewan laboratorium. Monyet ekor panjang (MEP) atau Macaca fascicularis merupakan salah satu satwa yang digunakan sebagai hewan laboratorium dan/atau hewan model, karena memiliki kedekatan filogenetik maupun kemiripan anatomi dan tingkah laku yang sama dengan manusia. Penangkaran merupakan salah satu upaya mendukung pengembangan MEP. Pengelolaan dan penggunaan MEP di penangkaran harus memenuhi prinsip-prinsip bioetika pemanfaatan hewan dan mengedepankan kaidah kesejahteraan hewan (animal welfare) (Mellor, 2016). Pengelolaan dan penggunaan satwa primata sebagai hewan laboratorium harus didukung dengan manajemen kesehatan satwa yang baik.

Permasalahan yang masih belum dapat diatasi dalam manajemen kesehatan satwa primata di penangkaran, salah satunya diare. Kejadian diare masih menjadi penyebab tingginya angka morbiditas dan mortalitas pada penangkaran satwa primata, serta berakibat pada penurunan produktivitas yang dapat memengaruhi pengunaannya dalam penelitian biomedis (Prongay et al., 2013). Hasil penelitian Wahyuni (1999) melaporkan bahwa tingkat keterpaparan bakteri enteropatogen dan kejadian diare pada MEP di fasilitas penangkaran MEP IPB Dramaga Bogor cukup tinggi, dengan hasil identifikasi bakteri enteropatogen sebagai berikut: terpapar Escherichia coli 46,37\% dengan kejadian diare $7,5 \%$; terpapar Campylobacter sp. 31,48\% dengan kejadian diare 5,83\%; terpapar Salmonella sp. 16,10\% dengan kejadian diare 1,67\%, dan terpapar Shigella sp. $6,05 \%$ dengan kejadian diare $0,83 \%$.

Menurut Boardman (2009), diare pada satwa primata dapat disebabkan oleh beberapa faktor, yaitu stres, malnutrisi, infeksi bakteri, virus, dan endoparasit. Selain itu, penularan diare dapat melalui air dan pakan yang terkontaminasi bakteri (Leclerc et al., 2002). Upaya pengendalian dan penanggulangan bakteri enteropatogen dapat dilakukan dengan mengetahui jenis bakteri yang menginfeksi MEP dan sumber penularannya, sehingga terapi intervensi klinis yang tepat dapat dilakukan. Oleh karena itu, penelitian ini bertujuan mengidentifikasi bakteri enteropatogen dari sampel feses MEP yang diare, dari sampel pakan dan air minum MEP, serta memperoleh data kepekaan bakteri enteropatogen terhadap antibiotik yang diisolasi dari sampel diare terhadap beberapa antibiotik.

\section{METODE PENELITIAN}

Penelitian dilaksanakan di Fasilitas Penangkaran MEP Institut Pertanian Bogor (IPB) Dramaga, Laboratorium Mikrobiologi, Fakultas Kedokteran Hewan IPB, Laboratorium Produktivitas dan Lingkungan Perairan (ProLing) Fakultas Perikanan dan Kelautan IPB, serta Laboratorium Mikrobiologi, Pusat Studi Satwa Primata (PSSP) IPB pada bulan Februari sampai Juli 2019. Hewan yang diamati adalah kelompok MEP dalam kandang koloni di penangkaran yang mengalami dan tidak mengalami diare. Penelitian sudah memperoleh persetujuan dari Komisi Pengawasan Kesejahteraan dan Penggunaan Hewan Penelitian, Pengujian, Penangkaran, dan Pendidikan (IACUC No. IPB PRC-19-A002) dan persetujuan Komisi Biorisiko (IBC No. 009-PL-PSSP-032019).

Sebanyak 30 sampel feses diare MEP diambil secara ulas rektal menggunakan stik kapas steril dari 18 kandang di fasilitas penangkaran MEP IPB Dramaga. Sampel air diambil dari sumber mata air (sumur) dan bak penampung, serta keran air dari masing-masing kandang (Wanara, Safari, Stainless). Sampel pakan (monkey chow dan buah pisang) diambil dari gudang penyimpanan. Semua sampel 
selanjutnya dibawa ke laboratorium menggunakan kotak pendingin pada kisaran suhu $4{ }^{\circ} \mathrm{C}$.

\section{Isolasi dan Identifikasi Bakteri}

Isolasi $E$. coli dilakukan pada agar Mac Conkey (MC) dan agar Eosine Methylene Blue (EMB), sedangkan Salmonella sp. dan Shigella sp. pada agar Salmonella Shigella (SS). Bakteri diidentifikasi melalui pewarnaan Gram, uji Indole, Methyl Red, Voges Proskauer, Citrate (IMViC), uji Triple Sugar Iron (TSI), uji fermentasi karbohidrat (glukosa, laktosa, maltosa, manitol, dan sukrosa), uji urea, uji katalase, uji oksidase, dan untuk E. coli dilakukan uji patogenitas pada agar darah.

\section{Uji Bakteriologi Air dan Pakan}

Sampel air dan pakan diuji dengan metode Most Probable Number (MPN) atau Angka Paling Mungkin (APM) (SNI 2879 2008). Sebanyak $25 \mathrm{~mL}$ sampel air dan $25 \mathrm{~g}$ pakan, masing-masing dimasukkan ke dalam wadah steril. Larutan Buffered Pepton Water 0,1\% (BPW) ditambahkan sebanyak $225 \mathrm{~mL}$ ke dalam wadah yang berisi sampel, dihomogenkan selama 1-2 menit menjadi pengenceran $10^{-1}$. Pengenceran $10^{-2}$ diperoleh dengan menambahkan $1 \mathrm{~mL}$ suspensi pengenceran $10^{-1}$ menggunakan pipet steril ke dalam larutan 9 $\mathrm{mL}$ BPW 0,1\%. Cara yang sama selanjutnya dibuat pengenceran $10^{-3}$. Sebanyak $1 \mathrm{~mL}$ diambil masing-masing dari setiap pengenceran ke dalam tiga seri tabung Lauryl Sulfate Tryptose Broth (LSTB) yang berisi tabung durham, diinkubasi pada suhu $35{ }^{\circ} \mathrm{C}$ selama $24-48$ jam. Hasil uji dinyatakan positif apabila terbentuk gas di dalam tabung durham.

\section{Coliform}

Hasil biakan positif dipindahkan menggunakan jarum inokulasi dari setiap tabung LSTB ke dalam tabung Brilliant Green Lactose Broth Bile (BGLBB) yang berisi tabung durham dan diinkubasi pada suhu $35^{\circ} \mathrm{C}$ selama 48 jam. Hasil uji dinyatakan positif apabila terbentuk gas di dalam tabung durham. Selanjutnya tabel MPN digunakan untuk menentukan nilai MPN berdasarkan jumlah tabung BGLBB yang positif sebagai jumlah coliform per mililiter atau per gram.

\section{Escherichia coli}

Hasil biakan positif dipindahkan menggunakan jarum inokulasi dari setiap tabung LSTB ke dalam tabung Escherichia coli Broth (ECB) yang berisi tabung durham dan diinkubasikan pada suhu $45,5{ }^{\circ} \mathrm{C}$ selama $24 \pm 2$ jam. Jika hasilnya negatif diinkubasikan kembali selama \pm 48 jam. Hasil uji dinyatakan positif apabila terbentuk gas di dalam tabung durham. Tabel MPN digunakan untuk menentukan nilai MPN berdasarkan jumlah tabung ECB yang positif sebagai jumlah $E$. coli per mililiter atau per gram.

Isolasi bakteri dari tabung ECB yang positif dengan cara diambil koloni yang tumbuh dan dibuat goresan pada agar EMB dan diinkubasi pada suhu $35^{\circ} \mathrm{C}$ selama $18-24$ jam. Koloni yang diduga diambil dari masing-masing agar EMB dengan menggunakan ose dipindahkan ke agar miring TS dan diinkubasi pada suhu $35{ }^{\circ} \mathrm{C}$ selama 18-24 jam. Sampel selanjutnya dilakukan uji biokimia IMViC. Jumlah E. coli dinyatakan berdasarkan nilai MPN, isolasiidentifikasi, dan uji biokimia.

\section{Uji Kepekaan Antibiotik}

Setiap isolat dilakukan uji kepekaan terhadap beberapa antibiotik (amoksisilin, ampicilin, eritromisin, gentamisin, oksitetrasiklin, sefalotin, dan siprofloksasin) menggunakan metode Kirby-Bauer. Isolat yang digunakan berumur 24 jam pada agar miring TS. Isolat diencerkan dalam $\mathrm{NaCl}$ 0,9\% sampai mempunyai tingkat kekeruhan yang sama dengan standar kekeruhan McFarland 0,5 (mengandung bakteri sebanyak $1,5 \times 10^{8} \mathrm{CFU} /$ $\mathrm{mL}$ ). Uji kepekaan dilakukan dengan menggoreskan larutan isolat bakteri ke agar Mueller Hinton secara merata dengan stik kapas steril, kemudian masing-masing cakram antibiotik diletakkan pada permukaan agar Mueller Hinton, selanjutnya diinkubasi pada suhu $37{ }^{\circ} \mathrm{C}$ selama 24 jam. Daerah yang dihambat, diukur diameternya untuk menentukan sensitif, intermediet, dan resistan berdasarkan standar interpretasi Clinical and Laboratory Standards Institute (CLSI 2015).

\section{HASIL DAN PEMBAHASAN}

\section{Tingkat Keterpaparan Bakteri Ente- ropatogen}

Pengambilan sampel feses pada 18 kandang koloni menunjukkan sebanyak 30 ekor MEP dari 310 ekor mengalami diare. Hasil isolasi dan identifikasi bakteri enteropatogen dari sampel feses ditemukan bakteri dari keluarga 
enterobacteriaceae, yaitu E. coli 100\% (30/30), Salmonella sp. 97\% (29/30), dan Shigella sp. 60\% (18/30).

\section{Escherichia coli}

Pemeriksaan tiga puluh sampel feses diare MEP menunjukkan hasil positif terhadap bakteri $E$. coli. Hal ini dilihat dengan adanya pertumbuhan koloni hijau metalik pada agar EMB dan koloni merah muda pada agar MC yang merupakan media spesifik $E$. coli. Perubahan warna hijau metalik pada agar EMB karena $E$. coli memfermentasi laktosa yang mengakibatkan peningkatan kadar asam dalam media. Kadar asam yang tinggi dapat mengendapkan methylen blue dalam media EMB (Lal dan Cheeptham, 2007). Kejadian diare dengan ditemukannya $E$. coli juga dilaporkan Kolappaswamy et al. (2014) pada koloni MEP dan M. mullata. Menurut Okwori et al. (2014) tingginya tingkat kehadiran atau prevalensi isolat $E$. coli yang ditemukan dalam sampel hewan, karena sebagian besar $E$. coli merupakan mikroflora normal usus, meskipun beberapa merupakan enterik patogen. Patotipe patogen pada hewan yang paling penting dan menyebabkan diare di antaranya enterotoxigenic E. coli (ETEC), enteropathogenic E. coli (EPEC), shiga toxin (stx) producing E. coli (STEC), dan extraintestinal pathogenic E. coli (EIEC) (Gyles dan Fairbrother, 2010).

Identifikasi $E$. coli patogen dalam penelitian ini dilakukan melalui isolasi pada media agar darah. Semua isolat $E$. coli pada agar darah menunjukkan perubahan zona bening kekeruhan sekitar koloni dengan adanya perubahan warna hijau. McKane dan Kandel (1998) menyatakan bahwa bakteri yang memiliki kemampuan melisiskan eritrosit secara sempurna dan membentuk zona bening di sekitar tempat pertumbuhan bakteri digolongkan ke dalam â-hemolisis. Jika kerusakan yang terjadi tidak sempurna dan hanya terjadi kebocoran pada eritrosit, maka dilihat zona yang tidak terlalu jernih dan sering disertai perubahan warna, sehingga media menjadi kehijauan sampai kecoklatan dan dikelompokkan sebagai á-hemolisis. Berdasarkan rentang waktu dapat dilihatnya zona jernih kekeruhan pada koloni, maka disimpulkan bahwa jenis hemolisis yang dihasilkan $E$. coli yaitu á-hemolisis dan termasuk bakteri patogen. Data yang diperoleh May et al. (2000) dari model infeksi patogenesitas á-hemolisis $E$. coli secara in vivo dan in vitro menunjukkan toksisitas hemolisis terhadap berbagai sel dan organ mamalia.

\section{Salmonella sp.}

Hasil isolasi dan identifikasi bakteri dari 30 sampel diare MEP, menunjukkan sebanyak 29 sampel positif terhadap Salmonella sp. yang diketahui melalui tumbuhnya koloni pada agar SS berwarna hitam pada bagian tengah koloni dengan tepiannya tidak berwarna yang disertai serangkaian uji biokimia. Salmonella sp. mampu hidup di tanah, air, dan pada berbagai permukaan, sehingga memungkinkan adanya peningkatan untuk menginfeksi individu hewan lain (Winfield dan Groisman, 2003).

Kejadian salmonellosis erat kaitannya dengan konsumsi pakan dan air yang terkontaminasi. Iklim dan faktor lingkungan berperan penting terhadap kejadian salmonellosis yang secara signifikan memengaruhi kemampuan Salmonella sp. bertahan di alam, khususnya ketika berada dalam kondisi yang tidak ideal dan memperoleh resistansi dari berbagai antibiotik (Abulreesh 2012).

\section{Shigella sp.}

Hasil isolasi dan identifikasi bakteri dari 30 sampel diare MEP, menunjukkan bahwa sebanyak 18 (60\%) sampel positif terhadap Shigella sp. yang diketahui melalui tumbuhnya bakteri pada agar SS dengan ciri koloni tidak berwarna atau bening. Shigellosis merupakan penyakit yang disebabkan Shigella sp. dengan tingginya angka kematian pada satwa primata di penangkaran dan pernah dilaporkan menewaskan 20 ekor $M$. mullata di Himachal Pradesh, India (Kurade et al., 2006). Penyebaran Shigella sp. sangat tinggi dengan dosis infeksinya yang sangat rendah, yaitu sekitar $10^{2}$ bakteri sudah menyebabkan infeksi pada satwa primata (Fowler dan Miller, 2003). Penyebaran Shigella sp. dapat melalui rute fekal oral dan kontak langsung antara petugas dan koloni satwa primata. Oleh karena itu, upaya yang dapat dilakukan pada penangkaran satwa primata, yaitu desinfeksi dan sanitasi secara berkala, serta mengevaluasi risiko penularan bakteri melalui pakan dan air minum (Islam et al., 2013).

\section{Bakteriologi Air dan Pakan}

Sebanyak enam sampel air yang diuji menunjukkan adanya $E$. coli dan coliform di atas batas minimum (Tabel 1) yang menandakan bahwa air ini tidak memenuhi syarat untuk 
dikonsumsi (SK Menkes, 2002). Menurut Permenkes (2010), nilai MPN untuk air minum adalah 0/100 mL sampel yang artinya dalam $100 \mathrm{~mL}$ air minum tidak boleh terdapat $E$. coli dan coliform.

Sumber air pada kandang Wanara berasal dari air sungai yang telah melalui proses penjernihan dan ditampung menggunakan tangki air, sedangkan kandang Safari dan Stainless sumber airnya dari sumur yang berbeda. Teridentifikasinya E. coli dan coliform pada sampel air kandang Wanara, kemungkinan karena tercemar feses pada air sungai dan proses penjernihan belum mampu mengurangi jumlah bakteri dalam air. Cemaran E. coli dan coliform pada air sumur juga dilaporkan Sunarti (2015). Hal ini dapat disebabkan kondisi sumur yang berlumut dan tidak tertutup, jarak septic tank dan sumur di fasilitas penangkaran yang berdekatan, serta kemungkinan konstruksi dasar lubang septic tank mengalami kebocoran, sehingga terjadinya perembesan air dari septic tank ke dalam tanah mencapai saluran air bawah tanah. Syarat jarak minimum septic tank dengan sumur adalah 10 meter (SNI 2398, 2017). Cemaran yang ditemukan pada air keran disebabkan bakteri kontaminan dapat masuk karena sistem sanitasi yang buruk, sehingga membentuk koloni dan tumbuh dalam sistem distribusi air.

Hasil pemeriksaan sampel pakan (Tabel 2.) menunjukkan adanya coliform pada pakan MEP. Adanya coliform pada buah pisang kemungkinan oleh kontaminasi feses pada air yang digunakan selama kegiatan sebelum dan sesudah panen, paparan selama transportasi, kondisi penyimpanan yang tidak tepat dan penanganan yang buruk (Gultie dan Sahile, 2013). Teridentifikasinya coliform pada monkey chow, karena adanya bahan pakan yang menjadi media pembawa mikroorganisme (Ebeneezar et al., 2018).

\section{Kepekaan Antibiotik}

Hasil pengujian resistansi antibiotik E. coli (Tabel 3.) menunjukkan tingkat resistansi

Tabel 1. Hasil pemeriksaan bakteriologi pada sampel air minum untuk monyet ekor panjang di Fasilitas Penangkaran MEP Institut Pertanian Bogor (IPB) Dramaga, Bogor

\begin{tabular}{llrr}
\hline \multirow{2}{*}{ Sampel Air } & Sumber & \multicolumn{2}{c}{ Bakteri } \\
\cline { 3 - 4 } & & Coliform $\mathrm{MPN} / \mathrm{mL}$ & E. coliMPN/mL \\
\hline Wanara 1 & Air penjernihan IPB & 92000 & 92000 \\
Wanara 2 & Air sumur Safari & 540 & 540 \\
Safari 1 & & 350 & 350 \\
Safari 2 & Air sumur Stainless & 1600 & 1600 \\
Stainless 1 & & 1600 & 1600 \\
Stainless 2 & & 1600 & 1600 \\
\hline
\end{tabular}

Keterangan: Wanara 1 (sampel air dari bak penampung), wanara 2 (sampel air dari keran pada kandang wanara), safari 1 (sampel air dari sumur), safari 2 (sampel air dari keran pada kandang safari), stainless 1 (sampel air dari sumur), stainless 2 (sampel air dari keran pada kandang stainless).

Tabel 2. Hasil pemeriksaan bakteriologi pakan monyet ekor panjang dalam penangkaran di Fasilitas Penangkaran MEP Institut Pertanian Bogor (IPB) Dramaga, Bogor

\begin{tabular}{lcc}
\hline \multirow{2}{*}{ Sampel } & \multicolumn{2}{c}{ Bakteri } \\
\cline { 2 - 3 } & ColiformMPN/g & E. coliMPN/g \\
\hline Pisang & 21 & - \\
Monkey Cow & 64 & - \\
\hline
\end{tabular}

tertinggi pada antibiotik eritromisin (100\%). Hal ini sejalan dengan penelitian Abo-State et al. (2012) dan Kallau et al. (2018) yang menunjukkan tingkat resistansi yang tinggi pada isolat E. coli. Menurut Plumb (1999) sebagian besar enterobacteriaceae telah mengalami resistan terhadap eritromisin. Resistansi E. coli terhadap eritromisin karena adanya gangguan pada sintesis protein bakteri disebabkan perubahan kelompok metil yang diproduksi $E$. coli menjadi inhibitor eritromisin untuk berikatan dengan subunit 50S (Luby et al., 2016). 
Beberapa isolat E. coli juga mengalami resistansi antibiotik seperti ampisilin (47\%), dan oksitetrasiklin (43\%), sehingga perlu diwaspadai karena dapat meningkat di waktu yang akan datang. Hal penting lainnya, potensi menjadi resistansi ditunjukkan pada beberapa antibiotik dengan tingkat resistansi intermediet yang dapat menjadi ancaman jika kontrol penggunaan antibiotik tidak dipertimbangkan.

Pengujian resistansi antibiotik pada isolat Salmonella sp., menunjukkan resistansi ampisilin dan eritromisin masing-masing $100 \%$, sefalotin $89,65 \%$, dan amoksisilin 65,51\% (Tabel 3). Amoksisilin, ampisilin dan sefalotin termasuk antibiotik golongan beta-laktam yang dilaporkan memiliki resistansi terhadap Salmonella sp. (Tekintas et al., 2017). Resistansi ampisilin dan amoksisilin dimungkinkan karena penggunaannya dalam pengobatan di fasilitas penangkaran ini. Peningkatan resistansi ampisilin pada Salmonella sp. diungkapkan Vatopoulos et al. (1994), karena evolusi jenis fag baru Salmonella sp. sehubungan dengan penyebaran plasmid ca.34-MDa yang resistan terhadap ampisilin. Selain itu, hasil uji yang bersifat intermediet oleh oksitetrasiklin sebesar $100 \%$ dan siprofloksasin 41,37\%. Threlfall dan Ward (2001) juga melaporkan penurunan kepekaan Salmonella sp., terhadap siprofloksasin

Isolat Shigella $s p$. telah mengalami resistansi terhadap beberapa antibiotik di antaranya: ampisilin dan eritromisin masingmasing $72,22 \%$, sefalotin $50 \%$, oksitetrasiklin $33,33 \%$, dan amoksisilin 27,78\% (Tabel 3). Penelitian yang dilakukan Kim et al. (2017) menunjukkan tingkat resistansi eritromisin (88\%), ampisilin (50\%) dan amoksisilin (60\%) pada satwa primata di institusi penelitian biomedis. Resistansi pada ampisilin kemungkinan karena penggunaan untuk pengobatan yang dilakukan di fasilitas penangkaran ini.

Resistansi antibiotik merupakan dampak yang terjadi akibat pemakaian antibiotik. Dzidic et al. (2008) menyatakan bahwa mekanisme terjadinya resistansi terbagi menjadi dua aspek, yaitu biokimia dan genetik. Aspek biokimia dengan proses inaktivasi antibiotik, modifikasi target, efflux pumps, dan mengubah permebialitas dari outer membrane. Aspek genetik melalui mutasi dan transfer material genetik secara horisontal.

Tingkat sensitivitas antibiotik yang baik ditunjukkan oleh siprofloksasin dan gentamisin terhadap E. coli, Salmonella sp., dan Shigella sp. (Tabel 3). Saeed et al. (2015) melakukan pengujian sensitivitas antibiotik dari kejadian diare dengan hasil uji sensitivitas siprofloksasin terhadap E. coli (93\%), Salmonella sp. (88\%), Shigella sp. (78\%), dan antibiotik gentamisin terhadap E. coli (94\%), Salmonella sp (100\%). dan Shigella sp (78\%). Hal ini membuktikan bahwa kedua agen antibiotik ini masih memiliki tingkat sensitivitas yang tinggi dan dapat menjadi pilihan untuk pengobatan diare.

\section{SIMPULAN}

Identifikasi enteropatogen feses diare MEP menunjukkan secara berturut-turut tingkat keterpaparan bakteri $E$. coli tertinggi, diikuti Salmonella sp., dan Shigella sp. Ketiga bakteri ini memiliki tingkat sensitivitas yang baik terhadap antibiotik siprofloksasin dan gentamisin, serta resistansi tertinggi ditunjukkan pada antibiotik eritromisin. Adanya kontaminasi bakteri E. coli dan coliform pada sampel air dan pakan yang dihitung tidak memenuhi syarat untuk dikonsumsi, serta memungkinkan terjadinya penularan pada MEP.

\section{SARAN}

Perlu dilakukan: 1) intervensi pada air sebagai upaya penurunan jumlah bakteri dan kejadian diare, 2) identifikasi endoparasit dan virus yang juga mungkin menyebabkan diare pada MEP, dan 3) penelitian lebih lanjut tentang efektivitas penggunaan antibiotik sensitif untuk mengeradikasi bakteri E. coli, Salmonella sp., dan Shigella sp.

\section{UCAPAN TERIMA KASIH}

Penulis mengucakan terima kasih kepada Dr drh Raden Putratama Agus Lelana, SpMP, MSi (Almarhum) untuk saran dan bimbingan terhadap kesempurnaan penelitian dan tulisan ini.

\section{DAFTAR PUSTAKA}

Abo-State MA, Mahdy HM, Ezzat SM, Abd El Shakour EH, El-Bahnasawy MA. 2012. Antimicrobial resistance profiles of enterobacteriaceae isolated from rosetta branch of river ile, Egypt. World Appl Sci 
J. 19-(9): 1234-1243. doi: 10.5829/ idosi.wasj.2012.19.09.2785.

Abulreesh HH. 2012. Salmonellae in the environment. Di dalam: Annous BA, Gurtler JB, editor. Salmonella-Distribution, Adaptation, Control Measures and Molecular Technologies. Kroasia (HR). InTech. Hlm. 19-50.

Boardman W. 2009. Differential Diagnosis of Diarrhoea in Primates. 2nd Ed. Pan African Sanctuary Alliance Primate Veterinary Healthcare Manual. https://www.yumpu. com/en/document/view/27763789/panafrican-sanctuary-alliance-primateveterinary-wildpro

[CLSI] Clinical and Laboratory Standards Institut. 2015. Performance standards for antimicrobial susceptibility testing. Twentyfifth informational supplement. M100-S25, Vol 35 No. 3.

Dzidic S, Suskovic J, Kos B. 2008. Antibiotic resistance mechanisms in bacteria: Biochemical and genetic aspects. Food Technol Biotechnol 46(1): 11-21.

Ebeneezar S, Sankar TV, Kishore P, Panda SK, Prabu DL, Chandrasekar S, Wilson L, Vijayagopal P. 2018. Evaluation of quality of commercial fish feeds in India with respect to microbiological parameters. Int J Curr Microbiol App Sci 7(2): 1478-1483. doi:https:/ /doi.org/10.20546/ijcmas.2018.702.179.

Fowler ME, Miller RE. 2003. Zoo and Wild Animal Medicine. 3th ed. Philadelphia. Elsevier Science.

Gultie A, Sahile SI. 2013. Microbial spectrum of fruit in Gondar Town Markets, North Western Ethiopia. J Microbiol Res 3(1): 110. doi: 10.5923/j.microbiology.20130301.01.

Gyles CL, Fairbrother JM. 2010. Escherichia coli, dalam: Gyles CL, Prescott JF, Songer G, Thoen CO. Pathogenesis of Bacterial Infections in Animals. Edisi ke-4. Iowa. Blackwell Pub.

Islam D, Ruamsap N, Khantapura P, Aksomboon A, Srijan A, Wongstitwilairoong B, Bodhidatta L, Gettayacamin M, Venkatesan MM, Mason CJ. 2013. Evaluation of an intragastric challenge model for Shigella dysenteriae 1 in rhesus monkeys (Macaca mulatta) for the pre-clinical assessment of Shigella vaccine formulations. APMIS 122: 463-475. doi: 10.1111/apm.12168.

Kallau NHG, Wibawan IWT, Lukman DW, Sudarwanto MB. 2018. Detection of multidrug resistant (MDR) Escherichia coli and tet gene prevalence at a pig farm in Kupang, Indonesia. J Adv Vet Anim Res 5(4): 388396. http://doi.org/10.5455/javar.2018.e289.

Kim J, Coble DJ, Salyards GW, Bower JK, Rinaldi WJ, Plauche GB, Habing GG. 2017. Antimicrobial use for and resistance of zoonotic bacteria recovered from nonhuman primates. Comp Med 67(1): 79-86.

Kolappaswamy K,Nazareno J, Porter WP, Klein HJ. 2014. Outbreak of pathogenic Escherichia coli in an outdoor-housed nonhuman primate colony. J Med Primatol 43: 122-124. doi:10.1111/jmp.12099.

Kurade NP, Kishtwaria RS, Pati US, Mandiyal RK, Sahoo A, Asrani RK, Sirkeck A, Nagal KB, Agnihotri RK, Telang RS. 2006. Outbreak of shigellosis in rhesus monkeys (Macaca mulatta) in Himachal Pradesh. Indian J Vet Pathol 30(2): 44-45.

Lal A, Cheeptham N. 2007. Eosin-methylene blue agar plates protocol. Washington. American Society for Microbiology. Hlm. 17.

Leclerc H, Schwartzbrod, Dei-cas E. 2002. Microbial agents associated with waterborne diseases. Crit Rev Microbiol 28(4): 371-409. doi:10.1080/1040-840291046768.

Luby EM, Moorman TB, Soupir ML. 2016. Fate and transport of tylosin-resistant bacteria and macrolide resistance genes in artificially drained agricultural fields receiving swine manure. Sci Total Environ 550: 1126-1133. doi: 10.1016/j.scitotenv.2016.01.132.

May AK, Gleason TG, Sawyer RG, Pruett TL. 2000. Contribution of Escherichia coli alphahemolysin to bacterial virulence and to intraperitoneal alterations in peritonitis. Infect Immun 68(1): 176-183. doi: 10.1128/ iai.68.1.176-183.2000.

McKane L, Kandel J. 1998. Microbiology. Essentials and Applications. Edisi ke-2. Philadelphia. McGraw-Hill, Inc. 
Mellor DJ. 2016. Moving beyond the "five freedoms" by updating the "five provisions" and introducing aligned "animal welfare aims". Animals 6: 59. doi:10.3390/ ani6100059.

Okwori AEJ, Nwankiti O, Onaji AI, Aguoru CU, Ogbonna BIO, Attah A, Makut MD, Adikwu TI. 2014. Bacterial profiles associated with captive non-human primates in jos zoo, Nigeria. Int J Trop Dis Health 4(4): 394401. doi: 10.9734/IJTDH/2014/5807.

Permenkes (Peraturan Menteri Kesehatan). 2010. Persyaratan Kualitas Air Minum. No. 492/MENKES/Per/ IV/2010.

Plumb DC. 1999. Veterinary Drug Handbook. Ed ke-3. Iowa (US). Iowa State University Press.

Prongay K, Park B, Murphy SJ. 2013. Risk factor analysis may provide clues to diarrhea prevention in outdoor-housed rhesus macaques (Macaca mulatta). Am J Primatol 75(8): 872-882. doi:10.1002/ajp.22150.

[SK Menkes] Surat Keputusan Menkes RI. 2002. Syarat-syarat dan Pengawasan Kualitas Air Minum. No: 907/ Menkes/SK/VII/2002.

[SNI] Standar Nasional Indonesia 2897. 2008. Metode pengujian cemaran mikroba dalam daging, telur, dan susu, serta hasil olahannya. Badan Standarisasi Nasional.

[SNI] Standar Nasional Indonesia 2398. 2017. Tata cara perencanaan tangki septik dengan pengolahan lanjutan (sumur resapan, bidang resapan, up flow filter, kolam sanita. Badan Standarisasi Nasional.

Saeed A, Abd H, Sandstrom G. 2015. Microbial aetiology of acute diarrhoea in children under five years of age in Khartoum, Sudan. J Med Microbiol 64: 432-437. doi 10.1099/ jmm.0.000043.

Sunarti RN. 2015. Uji kualitas air sumur dengan menggunakan metode MPN (Most

Probable Numbers). Bioilmi 1(1): 30-34. https:/ /doi.org/https://doi.org/10.19109/ bioilmi.v1i1.1128

Tekintas Y, Yilmaz FF, Aydemir SS, Tunger A, Hosgor-Limoncu M. 2017. Investigation of the antimicrobial susceptibility profile, virulence genes, and epidemiologic relationship of clinical Salmonella isolates. Turk J Pharm Sci 15(2): 207-211. doi: 10.4274/tjps.32559.

Threlfall EJ, Ward LR. 2001. Decreased susceptibility to ciprofloxacin in Salmonella enterica serotype Typhi, United Kingdom. Emerg Infect Dis 7(3): 448-450.

Vatopoulos AC, Mainas E, Balis E, Threlfall EJ, Kanelopoulou M, Kalapothaki V, MalamouLada H, Legakis NJ. 1994. Molecular epidemiology of ampicillin-resistant clinical isolates of Salmonella enteritidis. J Clinical Microbiol 32(5): 1322-1325.

Wahyuni T. 1999. Bakteri enteropatogen pada monyet ekor panjang (Macaca fascicularis) tingkat keterpaparan dan pola kepekaannya terhadap beberapa antibiotik. [Tesis]. Bogor. Institut Pertanian Bogor.

Winfield MD, Groisman EA. 2003. Role of nonhost environments in the lifestyles of Salmonella and Escherichia coli. Appl Environ Microbiol 69(7): 3687-3694. doi: 10.1128/AEM.69.7.3687-3694.2003. 